\title{
Development of technology for powdered soy milk with the addition of coconut powder
}

\author{
Anna Yu. Orlova, Vera A. Gribkova*, Natalia N. Lebedeva, Anatoliy A. Slavyanskiy, and \\ Natalia $V$. Nikolaeva \\ K.G. Razumovsky Moscow State University of technologies and management (the First Cossack \\ University), Zemlyanoy Val str., 73, Moscow, 109004, Russia
}

\begin{abstract}
Soy is a cultivated herb that is high in vitamins, minerals, and other elements that provide many health benefits. The main reason why this product is valued is complete proteins, which are almost as nutritious as animal proteins. The problem of this study is that the market for soy products represents a large assortment of products; however, products with no lactose are produced insufficiently and in limited quantities. In connection with the presence of certain problems in this industry, the purpose of the study was the technology of developing dry soy milk with the addition of coconut powder, which makes it possible to expand the range of products that meet the needs of the population. Therefore, a technological line for the production of powdered soy milk with additives is proposed, consisting of the main operations: preparation of raw materials for further processing, drying and peeling of soybeans, grinding, adding components, dosing powders, mixing, filling, and packaging the finished product. The obtained results show that during the storage of dry soy milk with the addition of coconut powder and a food additive, its flowability does not change.
\end{abstract}

\section{Introduction}

Nowadays, consumers' interest in healthy food, which contains useful functional components with a positive effect on the physiological functions of the human body, has increased. The use of plant raw materials has broad prospects, as it is of great value due to the combination of biologically and physiologically active components $[1,2]$.

An alternative to the use of animal milk can be the use of plant-based milk and food products based on it. Herbal drinks using grains, oils, and legumes are functional drinks. The raw materials used in the production contain a unique set of irreplaceable components that have a beneficial effect on the structure and functions of the body [3].

Nowadays, drinks are used not only to quench thirst. Consumers are looking for the properties that can be aimed at increasing energy, fighting aging, fatigue, and various diseases, which can be part of their lifestyle. In recent years, these changes and developments have led to the emergence of new products in the protein industry, namely, there are plant-based cow's milk substitutes [4].

\footnotetext{
${ }^{*}$ Corresponding author: vera gribkova@list.ru
} 
It is assumed [5] that the market for alternatives based on plant-based milk will increase on average by $15 \%$ annually. In Russia, much attention is paid to soy milk, as it is a healthy alternative to cow's milk. However, in recent years, more and more attention has been paid to the use of grains, oilseeds and nuts in new food products, based on their functional properties [6].

To obtain an alternative to plant milk, comparable to cow's milk in appearance, taste, stability and nutritional value, it is necessary to solve a number of technological problems [7].

Lack of protein is considered as one of the main problems that people face. Therefore, in the context of a global shortage of this component, the best alternative to animal protein is vegetable raw materials. Soy serves as such raw material, which is a recognized source of protein, easy to digest and balanced. Soy proteins are unique in that their amino acid composition is almost identical to that of animal proteins. It is well known that the nutritional value of any product is determined not only by the uniqueness of the chemical composition, but also by the ability to be absorbed by the human body [8].

Soy milk powder does not contain lactose compared to cow's milk, so it can be consumed by people with intolerance to this component. Milk does not have a carcinogenic or metabolic effect on the human body. It lowers the level of "bad" cholesterol in the blood and therefore it is useful to consume dry soy milk as a food product. This product is rich in protein and fiber and is absorbed by the body without allergic reactions. [9].

Recently, the food market in Russia has been segmented, new specialized eco-products have appeared. Nowadays, the main groups of consumers of this product can be identified: people suffering from overweight or high cholesterol - 55\% of the population; with lactose intolerance - $18 \%$; fasting people - $16 \%$; adhering to a healthy lifestyle - $3 \%$; vegetarians $1 \%$ (Fig. 1) [10].

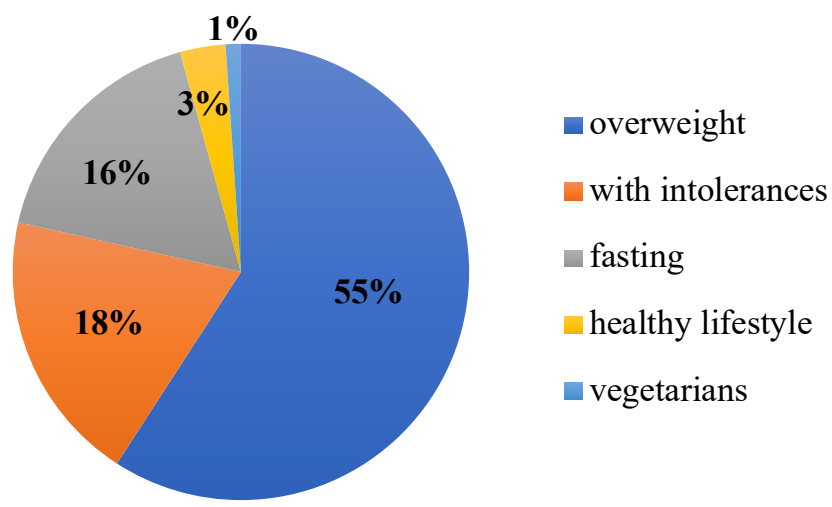

Fig 1. Categories of consumer groups of soy products

One of the important issues in Russia is the problem of protein deficiency in the nutrition of the population. It must be replenished, including with products based on vegetable protein [8].

For the health improvement of the country's population, new technological processes and food products are needed [11]. Therefore, soy milk is a complete replacement for natural milk, as it has a high biological value. It can be used for lactose intolerance and milk protein allergy. $[12,13]$. 


\section{Materials and methods}

Nowadays, protein deficiency requires solving the problems of proper nutrition and a healthy lifestyle. In connection with the presence of certain problems in this industry, the technology of dry soy milk with the addition of coconut powder was developed, which makes it possible to expand the range of goods that meet the needs of the population.

Powdered soy milk is a fine powder of yellow-cream color with a high content of vegetable protein and polyunsaturated fatty acids [14].

One of the ways to increase the nutritional value of dry soy products is to use coconut powder in its formulation, which is a source of essential fatty acids for the body [3].

In fig. 2 shows a machine-hardware diagram of a line for the production of dry soy milk with the addition of coconut powder.

The main stages in the production of such dry soy milk with the addition of coconut powder are the following technological operations:

- Reception and weighing of soybeans;

- Cleansing from impurities and removing stones;

- Drying and hulling of soybeans;

- Grinding;

- $\quad$ Addition of dry ingredients (dry coconut powder, additive E-551);

- $\quad$ Dosing of powders;

- Mixing;

- $\quad$ Filling and packaging of the finished product $[11,15]$.

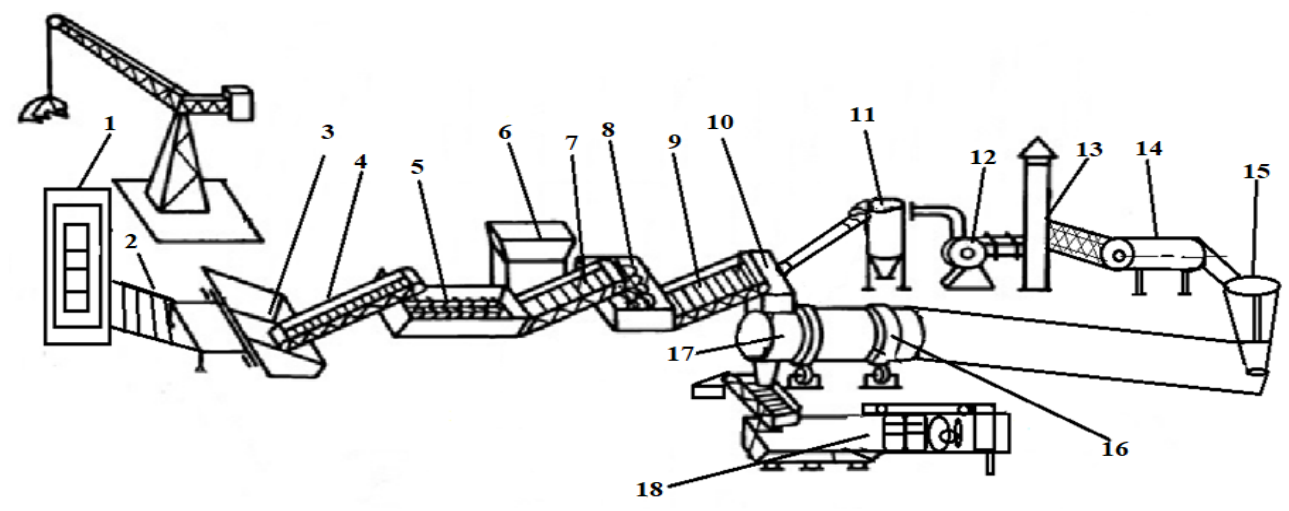

Fig. 2. Apparatus and technological diagram of the production line for the production of dry soy milk with the addition of coconut powder and the addition of E-551: 1 - receiving soybeans on the balance of production; 2 - conveyor belt; 3 - storage hopper (with installed weights); 4 - transporter; 5 sorting machine mesh; 6 - flushing chamber (with auger); 7 - conveyor; 8 - a sieve with a mesh diameter of 0.5-1 mm (inclined); 9 - drying chamber conveyor; 10 - drying chamber; 11 - steam generator; 12 - peeling unit; 13 - suction cyclone; 14 - fine grinding mill; 15 - component dosing hopper; 16 - mixer for uniform distribution; 17 - chilled powder storage hopper; 18 - packing machine

Reception and weighing of soybeans. Acceptance of soybeans is carried out in accordance with the requirements specified in the "Instruction for incoming control of soybean seeds" and established by the laboratory of the enterprise.

As needed, the beans send through the feed system to the hopper to keep the equipment running smoothly. The scales built into the hopper are used to keep track of the amount of processed raw materials. 
The soybeans are conveyed to the sorting machine, where they are cleared of debris (peel of dry pods, stalks, large stones of the earth). The number of beans loaded into the machine should not be large; this affects the quality of cleaning.

Washing of soybeans. The grains enter a washing chamber filled with water. Inside the chamber there is a drum with an auger, to which irrigation pipelines are connected, through which hot purified water with a temperature of $65^{\circ} \mathrm{C}$ is supplied for grain washing. The water flows down the pipe back to the chamber.

Cleansing from impurities and stones. Soybeans are served on a sieve with a slope with a mesh diameter of $0.5-1 \mathrm{~mm}$, so that stones can come out of the hatch and prevent the removal of beans with stones.

Drying and hulling of soybeans. The soybeans are fed to the dryer conveyor to evaporate excess moisture from the soybeans and improve husk removal. Hot air with a temperature of $75^{\circ} \mathrm{C}$ enters the drying chamber, which is heated by a steam generator. Cooling is carried out by air taken from the soybean preparation room.

The drying temperature is set and controlled so that the peel quality is $75-80 \%$. Temperature range from $100{ }^{\circ} \mathrm{C}$ to $150{ }^{\circ} \mathrm{C}$ (in the spring-summer period the drying temperature is from $100{ }^{\circ} \mathrm{C}$ to $135^{\circ} \mathrm{C}$, in the autumn-winter period from $135^{\circ} \mathrm{C}$ to $150{ }^{\circ} \mathrm{C}$ ).

The beans, under the influence of gravity, enter the shelling units, where they are mechanically processed (peeled). Due to the supply of air from below, the shell, as a lighter substance, rises up and removes by a cyclone from the total mass.

Grinding. After that, a vibrating conveyor sends the beans to a fine grinding mill for the fine grinding (grinding $0.2 \mu \mathrm{m}$ ).

Adding components (dry coconut powder, additive E-551). Prepared dry powder of coconut passes through sieves with an inclined arrangement with a mesh diameter of $0.5-1$ $\mathrm{mm}$ to remove various mechanical impurities during the manufacture and transportation of raw materials.

Dosing of powders. The base (fine dry powder of soybeans) and additives (ready-made dry coconut powder), as well as the component (anti-caking agent E-551) are sent to the bulk components dosing hopper, where the required dose is measured.

Mixing. The resulting fine powders ( 0.2 microns) are fed into the mixer to evenly distribute the ingredients throughout the entire mass of the product. During transportation, the dry powder cools by $10-15^{\circ} \mathrm{C}$. From the mixer, the cooled powder is fed to the storage hopper.

Packing and packaging of the finished product. The finished product from the storage hopper is fed into the packaging machine, where it is filled into kraft bags with polyethylene liners, $20-25 \mathrm{~kg}$ each. Then everything is sealed and sewn on a sewing machine.

\section{Results and discussion}

During the study of the preparation of powdered soy milk with the additive, the following quality indicators were identified: organoleptic, physicochemical.

Taste, smell, color and consistency play a decisive role in shaping the demand and aesthetic characteristics of a product, since its nutritional value and chemical composition are perceived as secondary by most consumers.

The developed soy milk powder with the addition of coconut powder should correspond to the organoleptic quality indicators presented in table 1 . 
Table 1. The results of the organoleptic assessment of the quality of the developed dry soy milk with additives

\begin{tabular}{|c|c|c|}
\hline \multirow{2}{*}{ Indicator name } & \multicolumn{2}{|r|}{ Characteristic } \\
\hline & $\begin{array}{l}\text { Soy milk powder } \\
\text { without additives }\end{array}$ & $\begin{array}{l}\text { Powdered soy milk with added coconut } \\
\text { powder }\end{array}$ \\
\hline Taste and smell & $\begin{array}{l}\text { Corresponding to } \\
\text { soybeans }\end{array}$ & $\begin{array}{c}\text { The characteristic smell of coconut powder, } \\
\text { does not have the smell of mold and other } \\
\text { foreign aromas }\end{array}$ \\
\hline $\begin{array}{l}\text { Appearance and } \\
\text { consistency }\end{array}$ & Dry soybean powder & $\begin{array}{c}\text { A powder consisting of agglomerated } \\
\text { particles of dry soybeans. A small amount } \\
\text { of lumps is allowed }\end{array}$ \\
\hline Colour & White & $\begin{array}{l}\text { White or creamy, uniform throughout the } \\
\text { mass }\end{array}$ \\
\hline Impurities & \multicolumn{2}{|r|}{ Not allowed } \\
\hline
\end{tabular}

Table 2 shows the physicochemical parameters of dry soy milk with the addition of coconut powder.

Table 2. The main physical and chemical parameters of the developed dry soy milk with additives

\begin{tabular}{|c|c|}
\hline Indicator name & Characteristic \\
\hline Moisture content, $\%$ & 4.0 \\
\hline Mass fraction of fat, $\%$ & 0.10 \\
\hline Mass fraction of protein, $\%$ & 19.0 \\
\hline Solubility index, $\mathrm{cm}^{3}$ & 0.4 \\
\hline
\end{tabular}

It was found that during the storage of dry soy milk with the addition of coconut powder and food additive E-551, its flowability does not change.

\section{Conclusion}

Thus, a technology has been developed for obtaining dry soy milk with the addition of coconut powder and an anti-caking agent (E-551), which meets the requirements for the functional properties of the product.

\section{References}

1. Simone R.B.M. Eussen, H. Verhagen, O. H. Klungel, J. Garssen, H. van Loveren, H. J. van Kranen, C. J. M. Rompelberga, Eur. J. Pharm., 668, S2-S9 (2011) https://doi.org/10.1016/j.ejphar.2011.07.008

2. Z. Ahmadian-Kouchaksaraei, M. Varidi, M. J. Varidi, H. Pourazarang, LWT - Food Sci. Techn., 57(1), 299-305 (2014) https://doi.org/10.1016/j.lwt.2013.12.028

3. O. E. Makinen, V. Wanhalinna, E. Zannini, and E. K. Arendt. Critic. Rev. Food Sci. Nutr., 56(3), 339-349 (2016) https://doi.org/10.1080/10408398.2012.761950 
4. S. Jiang, W. Cai, B. Xu. Foods, 2(2), 198-212 (2013) https://doi.org/10.3390/foods2020198

5. S. Dharmasena, O. Capps, Agric. Res. Econ. Rev., 43(1), 140-157 (2014) https://doi.org/10.1017/S106828050000695X

6. Y.E. Alozie, U.S. Udofia, World J. Dairy Food Sci., 10(2), 117-121 (2015)

7. O. Eslami, F. Shidfar, Compl. Therapies. Med., 42, 82-88 (2019) https://doi.org/10.1016/j.ctim.2018.11.001

8. J. K. Ikya, D. I. Gernah, H. E. Ojobo, O. K. Oni. Adv. J. Food Sci. Techn., 5(5), 543546 (2013) https://doi.org/10.19026/ajfst.5.3123

9. S. Sethi, S. K. Tyagi, R. K. Anurag, J. Food Sci. Techn., 53, 3408-3423 (2016) https://doi.org/10.1007/s13197-016-2328-3

10. P. I. Linnikov, Agric. Sci. J., 10, 81-86 (2018) https://doi.org/10.28983/asj.v0i10.595

11. M. Min, C.R. Bunt, S.L. Mason, M.A. Hussain, Crit. Rev. Food Sci. Nutr., 59 (16), 2626-2641 (2019) https://doi.org/10.1080/10408398.2018.1462760

12. N. Bordenave, M. Ferruzzi, Functional Foods and Beverages: In vitro Assessment of Nutritional, Sensory, and Safety Properties, 315 (USA, Wiley-Blackwell, 2018) https://doi.org/10.1002/9781118823309

13. I. E. Kozulina, O. M. Kurbacheva, N. I. Il'ina, Rus. Allerg. J., 11(3), 3-10 (2014) https://doi.org/10.36691/RJA483

14. A. L.Capriotti, G. Caruso, C. J. Cavaliere, Agric. Food Chem., 62(40), 9893-9899 (2014) https://doi.org/10.1021/jf5034152

15. A. Rajan, and G.R. Nair, Int. J. Food Sci. Techn., 45(10), 2023-2031 (2010) https://doi.org/10.1111/j.1365-2621.2010.02354.X 